\title{
Haemoglobin Lepore Boston-Washington in Sicily: clinical, haematological, and biosynthetic studies
}

\author{
G SCHILIRO, S MUSUMECI, G PIZZARELLI, A FISCHER, \\ M A ROMEO, AND G RUSSO
}

From the Department of Pediatrics, University of Catania, Catania, Sicily

SUMMARY In the south-east of Sicily 23 children from 14 unrelated families have been diagnosed as suffering from haemoglobin Lepore. Such a high incidence shows that Sicily is an important focus of haemoglobin Lepore. The results of haematological and biosynthetic studies in 18 carriers of $\mathrm{Hb}$ Lepore and in five double heterozygotes for $\mathrm{Hb}$ Lepore and $\beta$-thalassaemia are presented.

In the carriers the haematological and biosynthetic data are compared with carriers of $\beta$-thalassaemia, while the five double heterozygotes are compared with $\beta^{\circ}$ - and $\beta^{+}$-thalassaemia major subjects. In the carriers of $\mathrm{Hb}$ Lepore no synthesis of $\delta \beta$-chains was observed in peripheral blood cells; in fact we found a peak in the bone marrow. Double heterozygotes with circulating nucleated red cells showed $\delta \beta$-chain synthesis in peripheral blood.

Haemoglobin Lepore is a group of abnormal haemoglobins composed of normal $\alpha$-chains and fused $\delta \beta$-chains. The Lepore chains result from an unequal crossing over between linked $\delta$ - and $\beta$-genes during meiosis. ${ }^{1}$

Three different types of $\mathrm{Hb}$ Lepore result from three different crossing over points, $\mathrm{Hb}$ Lepore Hollandia $\left(\delta^{22}\right.$ to $\left.\beta^{50}\right), \mathrm{Hb}$ Lepore Baltimore $\left(\delta^{50}\right.$ to $\left.\beta^{86}\right)$, and $\mathrm{Hb}$ Lepore Boston-Washington ( $\delta^{87}$ to $\beta^{116}$ ).

These $\mathrm{Hb}$ Lepore are found chiefly among Mediterranean populations, but have also been found among other ethnic groups. ${ }^{2} 3$ In Italy, Campania has the highest number of cases of $\mathrm{Hb}$ Lepore $^{45}$ and in Sicily only one case has been found up to now. ${ }^{6}$

We report clinical, haematological, and biosynthetic studies in 14 unrelated Sicilian families with $\mathrm{Hb}$ Lepore, seen at the Department of Pediatrics of Catania from 1974 to 1979.

\section{Materials and methods}

In these families 18 members are carriers of $\mathrm{Hb}$ Lepore and five are double heterozygotes for $\mathrm{Hb}$ Lepore and $\beta$-thalassaemia. All the cases studied came from south-east Sicily. In all cases the disease was diagnosed by genetic studies and haematological data. In three randomly chosen families the

Received for publication 30 August 1979 fused $\delta \beta$-chains of one member were examined biochemically by Professor Tentori and his coworkers at the Istituto Superiore di Sanità, Centro Riferimento per le Talassemie ed Emoglobinopatie, Rome. Routine haematological studies were performed using standard methods. Estimation of $\mathrm{Hb}$ F was done by the method of Betke et al. ${ }^{7}$ Haemoglobins were analysed by electrophoresis on cellulose acetate in glycine buffer at $\mathrm{pH}$ 9. Quantitative analysis was carried out by elution of the various haemoglobins from cellulose acetate strips. Globin chain synthesis was performed by incubating washed red cells with ${ }^{3} \mathrm{H}$ leucine. In one case with $\mathrm{Hb}$ Lepore trait the globin synthesis was done in the bone marrow. After 2 hours the incubation was stopped and the cells were washed and lysed with distilled water. Globin was prepared by the acid acetone precipitation method of Rossi Fanelli et $a l^{8}$ and the globin chains were separated chromatographically on $\mathrm{CM}$ cellulose according to the method originally described by Clegg et al.$^{9}$ Routine haematological tests and haemoglobin synthesis in the double heterozygotes were done at the time of diagnosis before transfusion; in only one of them haemoglobin synthesis was also done after a high transfusion regimen.

\section{Results}

The haematological data of the 18 carriers are shown in table 1 . They are compared with carriers 
TABLE 1 Haematological findings in $\beta$-thalassaemia trait and Hb Lepore

\begin{tabular}{|c|c|c|c|c|c|c|c|c|c|c|}
\hline \multirow[t]{2}{*}{ Genotype } & \multirow{2}{*}{$\begin{array}{l}\text { No of } \\
\text { cases }\end{array}$} & \multirow{2}{*}{$\begin{array}{l}H b \\
(g / d l)\end{array}$} & \multirow{2}{*}{$\begin{array}{l}R B C \\
\left(\times 10^{6} \mathrm{~mm}^{3}\right)\end{array}$} & \multirow{2}{*}{$\begin{array}{l}M C H C \\
(g / d l)\end{array}$} & \multirow{2}{*}{$\begin{array}{l}M C H \\
(p g)\end{array}$} & \multirow{2}{*}{$\begin{array}{l}M C V \\
\left(\mu^{3}\right)\end{array}$} & \multicolumn{3}{|c|}{ Haemoglobins (\%) } & \multirow{2}{*}{$\begin{array}{l}\alpha-/ n o n-\alpha- \\
\text { ratio }\end{array}$} \\
\hline & & & & & & & $H b A_{2}$ & $H b F$ & $H b L$ & \\
\hline $\begin{array}{l}\text { Hb Lepore } \\
\text { trait } \\
\beta \text {-thalassaer }\end{array}$ & 18 & $\begin{array}{r}11.63 \\
\pm \quad 1.59\end{array}$ & $\begin{array}{r}5.02 \\
\pm 0.70\end{array}$ & $\begin{array}{c}31 \\
\pm 2 \cdot 38\end{array}$ & $\begin{array}{r}23 \cdot 14 \\
\pm \quad 1 \cdot 79\end{array}$ & $\begin{array}{r}75 \\
\pm 6 \cdot 38\end{array}$ & $\begin{array}{r}1.82 \\
\pm 0.47\end{array}$ & $\begin{array}{r}2.93 \\
\pm 1.43\end{array}$ & $\begin{array}{r}10 \cdot 14 \\
\pm \quad 1.87\end{array}$ & $\begin{array}{r}2.05 \\
\pm 0.33\end{array}$ \\
\hline trait & 15 & $\begin{array}{r}11.49 \\
\pm \quad 0.98\end{array}$ & $\begin{array}{r}4.55 \\
\pm 0.69\end{array}$ & $\begin{array}{r}30.08 \\
\pm \quad 4.87\end{array}$ & $\begin{array}{r}23.21 \\
\pm \quad 4.63\end{array}$ & $\begin{array}{r}75.83 \\
\pm 14.04\end{array}$ & $\begin{array}{r}5 \cdot 18 \\
\pm 1 \cdot 15\end{array}$ & $\begin{array}{r}1 \cdot 60 \\
\pm 1 \cdot 21\end{array}$ & & $\begin{array}{r}1 \cdot 76 \\
\pm 0 \cdot 35\end{array}$ \\
\hline
\end{tabular}

of $\beta$-thalassaemia. In both groups the morphological red cell alterations, osmotic fragility, MCV, $\mathrm{MCHC}$, and $\mathrm{MCH}$ were very similar. However, the values of $\mathrm{Hb} \mathrm{A}_{2}$ were constantly low in subjects with Lepore trait (mean value $1 \cdot 81 \pm 0.47$ ), while
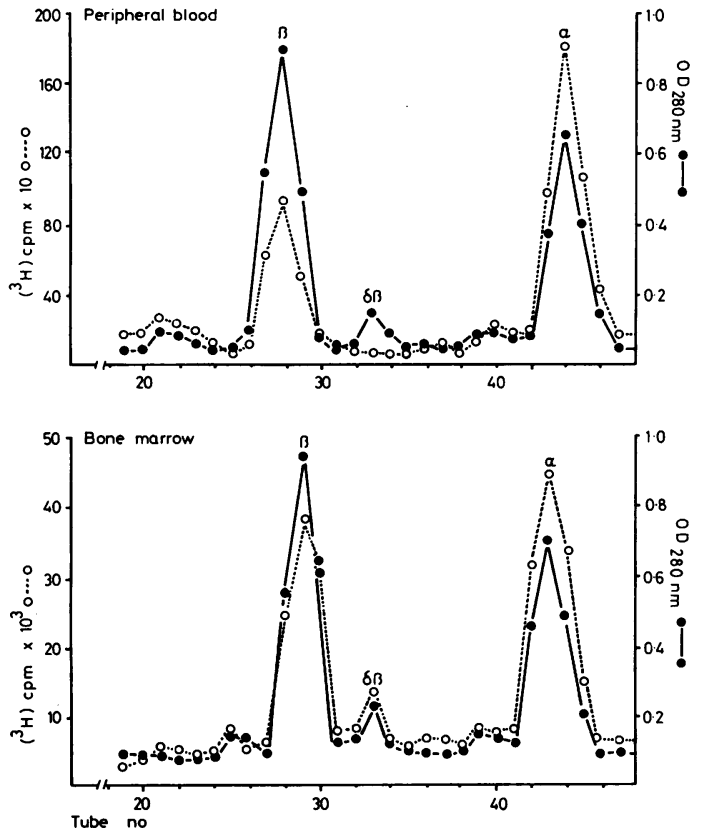

FIG 1 Carboxymethylcellulose chromatography of peripheral blood (top) and bone marrow in $\mathrm{Hb}$ Lepore trait. in $\beta$-thalassaemia trait the mean value was $5 \cdot 18 \pm 1 \cdot 15$. This difference was statistically significant $(\mathrm{p}<0.01)$.

The levels of fetal haemoglobin were slightly raised, with a mean value of $2.93 \pm 1.46$. In $\delta$-thalassaemia trait the mean value was $1 \cdot 60 \pm 1 \cdot 21$. However, this difference was not statistically significant $(\mathrm{p}<0 \cdot 10)$. The mean value of $\mathrm{Hb}$ Lepore was $10 \cdot 14 \pm 1 \cdot 87$. Haemoglobin synthesis was similar in both groups showing a mild imbalance of $\delta$-chain synthesis. No radioactivity was observed corresponding with an optical $\delta \beta$ peak in any subject, but we found a $\delta \beta$ peak (fig 1) when haemoglobin synthesis was studied in the bone marrow. In the bone marrow, synthesis was more balanced $(\alpha-/ \beta$-ratio $1 \cdot 27)$ than in peripheral blood $(\alpha-/ \beta$ ratio $1 \cdot 90)$.

The haematological data of the five double heterozygotes are compared with $\beta^{0_{-}}$and $\beta^{+}$thalassaemia major subjects in table 2 . In three classes of patients the parameters were similar and the differences were not statistically significant. In the double heterozygotes the levels of haemoglobin Lepore were lower than in those with $\mathrm{Hb}$ Lepore trait, with a mean value of $5.6 \pm 1.06$. In the haemoglobin synthesis of four double heterozygotes we found a small radioactive peak corresponding with an optical peak (fig 2, table 3). One of them had measurable, although very low, levels of $\beta$-chain synthesis $\left(\beta^{+}\right.$-thalassaemia-Hb Lepore) while the others were characterised by the absence of $\beta$-chain synthesis ( $\beta^{0}$-thalassaemia-Hb Lepore). The $\delta \beta$ synthesis was very low, approximately 2 to $4 \%$

TABLE 2 Haematological findings in $\beta^{\circ}$-and $\beta^{+}$-thalassaemia major and double heterozygotes for $\beta$-thalassaemia and $H B$ Lepore

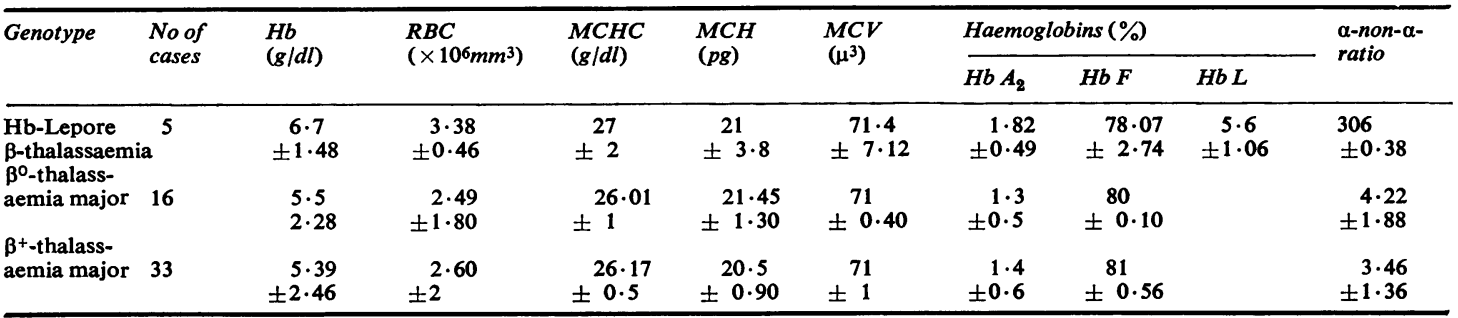



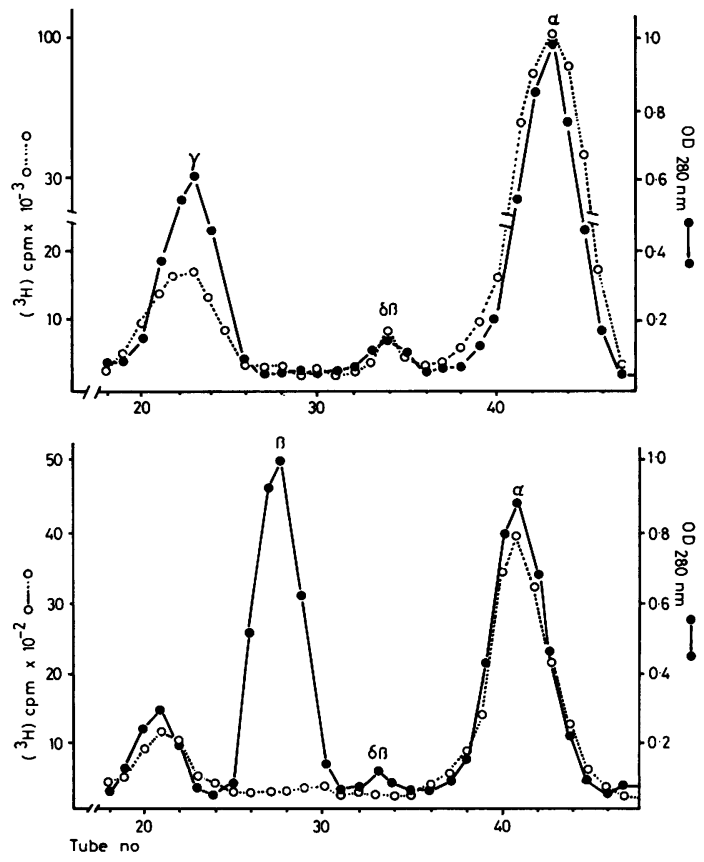

FIG 2 Carboxymethylcellulose chromatography of peripheral blood in double heterozygotes at diagnosis and after high transfusion regimen.

TABLE 3 Globin chain synthesis in peripheral blood cells in double heterozygotes for

HB Lepore- $\beta$-thalassaemia

\begin{tabular}{llllll}
\hline Patients & $\begin{array}{l}\text { Nucleated red cells } \\
\left(R B C / \mathrm{mm}^{3}\right)\end{array}$ & $\begin{array}{c}\alpha-/ \beta- \\
\text { ratio }\end{array}$ & $\begin{array}{c}\alpha-/ \gamma- \\
\text { ratio }\end{array}$ & $\begin{array}{c}\alpha-/ \delta \beta- \\
\text { ratio }\end{array}$ & $\begin{array}{c}\alpha-/ \text { non- } \alpha \\
\text { ratio }\end{array}$ \\
\hline 1 & 25000 & & $2 \cdot 96$ & $22 \cdot 79$ & $2 \cdot 62$ \\
2 & 30000 & $3 \cdot 39$ & $20 \cdot 34$ & $2 \cdot 90$ \\
3 & 30000 & & $3 \cdot 49$ & $42 \cdot 11$ & $3 \cdot 22$ \\
4 & 40000 & 15.85 & $5 \cdot 12$ & 37.80 & $3 \cdot 51$ \\
\hline
\end{tabular}

of $\alpha$-chain synthesis. Also $\gamma$-chain synthesis was reduced with an $\alpha-/ \gamma$-ratio of 2.96 to $5 \cdot 12$. This is similar to that found in homozygous $\beta$-thalassaemia. The four patients showed severe imbalance with a mean value of $\alpha-/$ non- $\alpha$-ratio of $3.06 \pm 0.49$. These mean values were slightly lower than in those suffering from $\beta^{\circ}$ - and $\beta^{+}$-thalassaemia major, but this difference was not statistically significant $(\mathrm{p}<0 \cdot 10)$.

\section{Discussion}

Because of the low numbers of subjects with $\mathrm{Hb}$ Lepore in the world, Lehmann and Huntsman ${ }^{10}$ stated that while this anomaly is very important from the theoretical point of view it is less important from the practical point of view. However, this paper shows a high number of subjects with $\mathrm{Hb}$ Lepore in Sicily, where $\beta$-thalassaemia trait is present with a frequency of $7.7 \%$, and other $\beta$-chain anomalies like $\mathrm{Hb} \mathrm{S}$ are present. ${ }^{11} 12$ Moreover, the interaction between $\mathrm{Hb}$ Lepore and $\beta$-thalassaemia or $\mathrm{Hb} \mathrm{S}$ presents a very severe and interesting clinical and haematological picture. ${ }^{2}$ Thus, this anomaly is of practical significance in Sicily. We found five double heterozygotes for $\beta$-thalassaemia and $\mathrm{Hb}$ Lepore with a clinical, haematological, and biosynthetic picture similar to Cooley's disease.

In three subjects where the isolation, purification, and identification of $\mathrm{Hb}$ Lepore were made, the crossing over was found between residue 87 of the $\delta$-chain and 116 of the $\beta$-chain. This is consistent with $\mathrm{Hb}$ Lepore Boston-Washington, ${ }^{13}$ which has been found almost exclusively in Mediterranean populations.

The clinical and haematological findings in carriers of $\mathrm{Hb}$ Lepore and $\beta$-thalassaemia are identical and these conditions can be distinguished only by haemoglobin electrophoresis.

Therefore, screening of haemoglobin without electrophoresis cannot detect subjects with $\mathrm{Hb}$ Lepore trait. Haemoglobin synthesis in peripheral blood was constantly imbalanced and no $\delta \beta$-chains were found. In the bone marrow of one carrier the synthesis of haemoglobin was almost balanced and $\delta \beta$-chains were synthesised. These results are in accordance with previously published findings. ${ }^{14-16}$ In four double heterozygotes we found an imbalance of haemoglobin synthesis similar to that seen in thalassaemia major, and they have severe transfusion dependent anaemia. These patients showed $\delta \beta$-chain synthesis in the peripheral blood and they had circulating nucleated red cells (25000 to $40000^{3}$ ) which could cause the production of these fused chains. When the haemoglobin synthesis was repeated in one of these subjects after a high transfusional regimen without circulating nucleated red cells no $\delta \beta$-chains were found (fig 2 ).

Our data confirm that $\delta \beta$-chain synthesis takes place during the early stages of erythroid cells and ends in reticulocytes. This phenomenon could be the result of instability of $\delta$ mRNA which then cannot be translated in the reticulocytes. ${ }^{17} 18$ In fact the fused $\delta \beta$ (Lepore) and $\beta \delta$ (anti-Lepore) chains are not synthesised in reticulocytes but only in erythroblasts. ${ }^{151619-21}$ Other fused chains without the $\delta$-chain sequence, like the $\gamma \beta$-chains of $\mathrm{Hb}$ Kenya, are synthesised in reticulocytes also. ${ }^{22} 23$

Recently Benz et $a,^{24}$ in four double heterozygotes for $\beta^{\circ}$-thalassaemia-Hb Lepore, did not 
find $\delta \beta$-chain synthesis in peripheral blood cells. Although not stated, these subjects had probably been polytransfused and so had no nucleated red cells. In the same subjects variable amounts of $\beta$-like mRNA were detected, but it is conceivable that this mRNA could have been contributed by the $\beta^{\circ}$-thalassaemia gene.

Forget et $a^{19}$ and Ramirez et al, ${ }^{25}$ in homozygous $\mathrm{Hb}$ Lepore with circulating nucleated red blood cells, found that the amount of $\beta$-like $(\delta \beta)$ mRNA in peripheral blood cells is proportional to the chain synthesis in the same cells.

We are grateful to Drs $\mathbf{R}$ Curreri and $\mathbf{R}$ Testa for their technical assistance.

\section{References}

1 Baglioni C. The fusion of two peptide chains in hemoglobin Lepore and its interpretation as a genetic deletion. Proc Natl Acad Sci USA 1962;48:1880-6.

2 Weatherall DJ, Clegg JB. The thalassaemia syndromes. 2nd ed. Oxford: Blackwell, 1972.

3 Efremov GD. Hemoglobins Lepore and anti-Lepore. Hemoglobin 1978;2:197-233.

4 Quattrin N, Ventruto V. Hemoglobin Lepore: its significance for thalassemia and clinical manifestations. Ann N Y Acad Sci 1974;232:65-75.

5 Esposito L, Ferrara M, Barbagallo E, Pinto L. Contributo allo studio delle emoglobine Lepore. Pediatria (Napoli) 1974;82:65-77.

- Masi M, Graziani B. La malattia da emoglobina Leporemicro-citemia. Descrizione di due nuovi casi. Prog Med 1967;24:340-6.

7 Betke K, Martin HR, Schlicht I. Foetal estimation of small percentages of haemoglobin. Nature 1959;184: 1877-8.

8 Rossi Fanelli AR, Antonini E, Caputo A. Studies on the structure of haemoglobin. I. Physiochemical properties of human globin. Biochim Biophys Acta 1958;30:608-15.

- Clegg JB, Naughton MA, Weatherall DJ. Abnormal human haemoglobins. Separation and characterization of the alpha and beta chains by chromatography and the determination of two new variants, $\mathrm{Hb}$ Chesapeake and Hb J (Bangkok). J Med Biol 1966;19:91-108.

10 Lehmann H, Huntsman RG. Man's haemoglobins. Amsterdam: North Holland, 1966.

11 Schilirò G. Sicily: the world reservoir for thalassemias and hemoglobinopathies. Nature $1978 ; 276: 761$.
12 Schilirò G, Musumeci S, Pizzarelli G, Di Gregorio L, Fischer A, Russo G. $\beta$-thalassemia in Sicily. Hematological and biosynthetic studies. Acta Haematol 1978; 60:193-200.

13 Baglioni C. Abnormal human hemoglobins. X. A study of hemoglobin Lepore (Boston). Biochim Biophys Acta 1965;97:37-46

14 Weissman SM, Jeffries I, Karon M. The synthesis of alpha, beta and delta peptide chains by reticulocytes from subjects with thalassemia or hemoglobin Lepore. J Lab Clin Med 1967;69:183-93.

15 White JM, Lang A, Lorkin PA, Lehmann H. Synthesis of haemoglobin Lepore. Nature 1972 ;235 :208-9.

16 Lang A, White JM, Lehmann H. Synthesis of Hb Lepore $\left(\alpha_{2} \delta \beta_{2}\right)$ : influence of $\delta$ and $\beta$ nucleotide sequence on synthesis of $\delta \beta$ chain. Nature 1972;240:268-70.

17 Darnell GE, Jelinek WR, Molloy CR. Biogenesis of mRNA: genetic regulation in mammalian cells. Science $1973 ; 181: 1215-6$.

18 Clegg JB, Weatherall DJ. $\beta^{\circ}$-thalassaemia. Time for a reappraisal ? Lancet $1974 ; 1: 133$.

19 Forget BG, Cavallesco C, Benz ES Jr, McClure PD, Hillman DG, Krieger H, Clarke B, Housman D. Studies of globin chain synthesis and globin mRNA content in a patient homozygous for hemoglobin Lepore. Hemoglobin 1978;2 (2):117-28.

20 Roberts AV, Clegg JB, Weatherall DJ, Otha Y. Synthesis in vitro anti-Lepore haemoglobin. Nature $1973 ; 245: 23$.

21 Luppis B, Vetruto V. Synthesis of alpha, beta and gamma chains by reticulocytes from brothers homozygous for haemoglobin Lepore. Acta Haematol 1979;61:216-21.

22 Huisman THJ, Wrightstone RN, Wilson JB, Schroeder WA, Kendall AG. Hemoglobin Kenia, the product of a fusion of $\gamma$ and $\beta$ polypeptide chains. Arch Biochem Biophys 1972;153:850-5.

23 Smith DH, Clegg JB, Weatherall DJ, Gilless HM. Hereditary persistence of foetal haemoglobin associated with a $\gamma \beta$ fusion variant, haemoglobin Kenya. Nature 1973;246:184-6.

24 Benz J Jr, Forget BG, Hillman DG, Cohen-Solal M, Pritchard S, Cavallesco C, Prensky W, Housman D. Variability in the amount of globin mRNA in $\beta^{\circ}$ thalassemia. Cell 1978;14:299-312.

25 Ramirez F, Mears JG, Nudel V, Bank A, Luzzatto L, Di Prisco G, D'Avino R, Pepe G, Camarbella L, Gambino R, Cimino R, Quattrin N. Defects in DNA and globin messenger RNA in homozygotes for hemoglobin Lepore. J Clin Invest 1979;63:736-42.

Requests for reprints to Dr G Schilirò, Department 옥 of Pediatrics, University of Catania, Viale A Doria, 95125 Catania, Sicily. 